\title{
Note \\ FRUIT CHARACTERIZATION OF VENEZUELAN AVOCADO VARIETIES OF MEDIUM OIL CONTENT
}

\author{
Vicente Manuel Gómez-López* \\ Instituto de Ciencia y Tecnología de Alimentos, Facultad de Ciencias, Universidad Central de Venezuela, Apartado \\ Postal 47097, Los Chaguaramos, Caracas 1041 A, Venezuela \\ *Corresponding author<gomezv@buho.ciens.ucv.ve>
}

\begin{abstract}
The objective of the present paper was to characterize some avocado fruit varieties to increase the information pool for this fruit. Twelve avocado varieties of medium oil content (8.09-11.12\%) from a Venezuelan orchard: Wilson Popenoe, Figueroa 1, Waldin, Puebla, Schaff, Celia, Araira FM, Adolfo, Esencia de la Vega, Lawhon, Winslowson, and Lujo were characterized for pulp oil and moisture; weight (whole fruit, seed, pulp, and peel); length, width, and fruit shape; peel characteristics (roughness, color and hand peeling); and ripeness time. Differences in oil content, moisture content and fruit weight were found when compared with results reported by other authors. The variety Puebla was the lightest $(107 \mathrm{~g})$ and the smallest $(7.90 \times 4.62 \mathrm{~cm})$, while Wilson Popenoe presented the highest pulp proportion (82\%). Most of the varieties were ovate, with rough green peel and easy to hand peel. Peak ripeness of some varieties was at 3-12 days. Potential yields of two varieties were higher that the Venezuelan average.
\end{abstract}

Key words: avocado, fruit characterization

\section{CARACTERIZAÇÃO DE VARIEDADES VENEZUELANAS DE ABACATE COM TEOR MÉDIO DE ÓLEO}

\begin{abstract}
RESUMO: O objetivo do presente trabalho foi caracterizar algumas variedades de abacate para aumentar 0 banco de informações desta fruta. Doze variedades de teor médio de óleo $(8,09-11,12 \%)$ de um pomar da Venezuela: Wilson Popenoe, Figueroa 1, Waldin, Puebla, Schaff, Celia, Araira FM, Adolfo, Esencia de la Veja, Lawhon, Winslowson e Lujo, foram caracterizadas em relação à umidade e teor de óleo da polpa; pesos (fruta inteira, semente, polpa, casca); comprimento, largura e forma da fruta; carcterísticas da casca (rugosidade, cor, descascamento manual); tempo de maturação. Diferenças de umidade, teor de óleo e peso foram encontradas em relação a resultados de outros autores. A variedade Puebla foi a mais leve (107 g) e a menor $(7,90 \times 4,632 \mathrm{~cm})$, enquanto a Wilson Popenoe apresentou a maior proporção de polpa (82\%). A maioria das variedades é oval, com pele verde e rugosa, de descascamento manual fácil. Produtividades potenciais de duas variedades foram maiores que a média venezuelana.

Palavras-chave: abacate, caracterização de fruto
\end{abstract}

\section{INTRODUCTION}

Avocado (Persea americana Mill.) is a popular fruit in Venezuela being cultivated in this country for the last five centuries (Avilán \& Ciurana, 1983). Although Venezuela is in the seventh place among the world producers, there are few specialized orchards. Agronomic studies in Venezuela to select the best varieties began in the 30's (Avilán et al., 1994). This work was designed to complement the agronomic studies in order to make an information pool useful to growers and researchers.

The high oil concentration of avocado, which can reach up to $40 \%$ on wet basis, is its main feature, and depends on the variety, orchard location and harvesting time (Pearson, 1975; Olaeta et al., 1986).

Avocado is also rich in three of the most important antioxidants (vitamins E, C and B-carotene), helps to prevent strokes due to its high potassium and low sodium content, provides exceptional quantities of soluble and insoluble dietary fiber, is a superior first solid food for babies, and its fat consists predominantly of monounsaturated oleic acid (Bergh, 1992).

Selection of varieties must include several approaches, a non-exhaustive list being included below. One approache would be to find a high yield variety, with low susceptibility to diseases (Rouse \& Knight Junior, 1991). Another one is quite variable and depends on the climatic and soil conditions as soil drainage (Avilán \& Rodríguez, 1992), altitude of the potential orchard (Figueroa, 1982); and consumer requirements, as a minimum oil content according to legal regulations (Lewis, 1978), a specific sort of size, color, peel roughness and shape depending on consumer habits (Storey et al., 1973/ 74); flavor (Lewis et al., 1979), amount of pulp fiber (Rouse \& Knight Junior, 1991), pulp tendency to brown (Lizana \& Luza, 1979), facility of hand peeling etc. In addition, another characteristics must be considered when production is oriented to the fresh or processed product market as a high 
pulp yield (Rouse \& Knight Junior, 1991) or to oil extraction, as high oil yield (Swisher, 1988). For this reason, to provide information of varietal characteristics, instead of stating a priori recommendations, growers and scientifics should choose the best varieties according to their own possibilities and targets. This was the aim of previous articles (Gómez-López, 1998, 1999) and of this one.

\section{MATERIAL AND METHODS}

Samples belong to the collection of Centro Nacional de Investigaciones Agropecuarias, Maracay, Venezuela; whose location and characteristics have been indicated previously (Gómez-López, 1998). In 1993, between 14 and 26 mature fruits of each of the following avocado ( $P$. americana Mill.) varieties from trees older than seven years were harvested: Waldin, Puebla, Schaff and Winslowson (from imported plants); Adolfo, Araira FM, Figueroa 1 and Lujo (Venezuelan varieties) (Avilán y Rodríguez, 1995); and Wilson Popenoe, Celia, Esencia de la Vega, and Lawhon. The samples were brought to Instituto de Ciencia y Tecnología de Alimentos, Caracas, and kept in ambiental conditions until ripe. A single fruit was considered ripe, when its skin was ruptured with a 0,8 $\mathrm{cm}$ width cylindrical plunger in an Instrom Universal Testing Machine model 1101, using a penetration speed of $1 \mathrm{~cm}$ $\mathrm{min}^{-1}$; the plunger penetrated the sample perpendicularly to the equator. Three fruits of each variety were measured in five points located equidistantly (Gómez-López, 1998). When samples were ripe, five fruits of each variety were randomly selected, and analytical determinations were performed.

Pulp moisture and oil contents were measured according to Gómez-López (1998) in a pulp pool from five fruits.

Fruit weight (whole fruit, seed, pulp, and peel); length, width at the widest point, and shape; and the peel characteristics roughness, hand peeling, and color were determined. Peel color results are the average of five readings taken equidistantly at the equator of the fruit, measured by a tristimulus colorimeter (Colormet, Metron Instruments Inc., Hamilton, Ontario, Canada) using the Lab Hunter System (Gómez-López, 1998). In this system, lightness scale goes from 0 (pure black) to 100 (pure white), positive values of "a" mean redness and the negative values greenness, positive values of "b" means yellowness and the negative values blueness (Francis \& Clydesdale, 1975). Means of TABLE 2 were compared by Kruskal-Wallis test, using the Statgraphics 6.0 program.

Estimated yields were calculated by multiplying the average number of fruits per tree according to Figueroa (1982), fruit weight (TABLE 2) and the recommended number of trees (228) per hectare (Avilán et al., 1994) to obtain $\mathrm{kg}$ of fruit ha ${ }^{-1}$. This value was then multiplied by the pulp ratio (TABLE 2 ) to obtain $\mathrm{kg}$ of pulp $\mathrm{ha}^{-1}$; and this result was multiplied by the pulp oil ratio (TABLE 1) to obtain the $\mathrm{kg}$ of oil ha ${ }^{-1}$.
TABLE 1 - Race ${ }^{\mathrm{a}}$, Floral Group ${ }^{\mathrm{a}}$, and Pulp Oil and Moisture Percentages of twelve Avocado. Varieties harvestedin Venezuela in 1993.

\begin{tabular}{|c|c|c|c|c|c|}
\hline Variety & Race $^{b}$ & $\begin{array}{l}\text { Floral } \\
\text { group }\end{array}$ & oilc & moisture ${ }^{d}$ & $\begin{array}{c}\text { oil + } \\
\text { moisture }\end{array}$ \\
\hline & \multicolumn{5}{|c|}{----- \% ------ } \\
\hline $\begin{array}{l}\text { Wilson } \\
\text { Popenoe }\end{array}$ & WI & A & 8.09 & 83.29 & 91.38 \\
\hline Figueroa 1 & nd & - & 8.56 & 82.52 & 91.08 \\
\hline Waldin & WI & A & 8.75 & 78.73 & 87.48 \\
\hline Puebla & $M$ & B & 8.94 & 78.79 & 87.73 \\
\hline Schaff & $G \times W I$ & A & 8.95 & 84.26 & 93.21 \\
\hline Celia & G & A & 9.57 & 78.00 & 87.57 \\
\hline Araira FM & G & A & 10.07 & 80.37 & 90.44 \\
\hline Adolfo & $G \times W I$ & A & 10.11 & 82.40 & 92.51 \\
\hline $\begin{array}{l}\text { Esencia de } \\
\text { la Vega }\end{array}$ & nd & 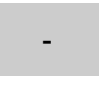 & 10.21 & 79.08 & 89.29 \\
\hline Lawhon & WI & B & 10.65 & 79.91 & 90.56 \\
\hline Winslowson & $G \times W l$ & B & 11.09 & 81.70 & 92.79 \\
\hline Lujo & $G \times W l$ & B & 11.12 & 78.76 & 89.88 \\
\hline
\end{tabular}

according to Avilán \& Rodríguez (1995). ' $\mathrm{M}$ : Mexican, G: Guatemalan, WI: West Indian, -: no determined. 'Data are averages of two samples of a five avocado pool. dData are averages of four samples of a five avocado pool.

TABLE 2 - Fruit Weight and Pulp, Seed and Peel Proportions ${ }^{a}$ of twelve 12 Avocado Varieties harvested in Venezuela in 1993.

\begin{tabular}{|c|c|c|c|c|}
\hline Variety & Weight & pulp & seed & peel \\
\hline & $g$ & & $---\%$ & \\
\hline $\begin{array}{l}\text { Wilson } \\
\text { Popenoe }\end{array}$ & $354.19^{\text {ef }}$ & $81.76^{e}$ & $9.11^{\mathrm{a}}$ & $9.13^{\mathrm{abc}}$ \\
\hline Figueroa 1 & $304.53^{\text {de }}$ & $65.06^{\mathrm{a}}$ & $26.39^{e}$ & $8.57^{a}$ \\
\hline Waldin & $176.28^{b}$ & $63.63^{a}$ & $25.93^{e}$ & $10.44^{b c}$ \\
\hline Puebla & $106.96^{a}$ & $63.23^{\mathrm{a}}$ & $26.00^{\mathrm{e}}$ & $10.78^{b c}$ \\
\hline Schaff & $621.06^{h}$ & $75.86^{d}$ & $13.37^{b}$ & $10.77^{\mathrm{bc}}$ \\
\hline Celia & $220.41^{c}$ & $62.99^{a}$ & $25.90^{\text {de }}$ & $11.11^{c}$ \\
\hline Araira FM & $361.20^{f}$ & $66.74^{a}$ & $25.95^{e}$ & $7.31^{a}$ \\
\hline Adolfo & $481.39^{g h}$ & $72.76^{b c}$ & $18.60^{\mathrm{cd}}$ & $8.64^{a}$ \\
\hline $\begin{array}{l}\text { Esencia de la } \\
\text { Vega }\end{array}$ & $203.44^{b c}$ & $66.00^{a}$ & $19.43^{\mathrm{cd}}$ & $14.58^{d}$ \\
\hline Lawhon & $286.84^{d}$ & $71.60^{\mathrm{bc}}$ & $19.17^{\mathrm{cd}}$ & $9.23^{b c}$ \\
\hline Winslowson & $504.23^{h}$ & $74.73^{c}$ & $16.33^{b c}$ & $8.93^{\mathrm{ab}}$ \\
\hline Lujo & $420.09^{f g}$ & $67.94^{\mathrm{ab}}$ & $23.40^{\text {cde }}$ & $8.65^{\mathrm{ab}}$ \\
\hline
\end{tabular}

aData are means of five avocados. Means within columns followed by the same letter are not signifintly different $(p<0.05)$.

\section{RESULTS AND DISCUSSION}

A gentle pressure applied by fingers is a common practice to assess avocado ripeness. Since that is not scientifically reproducible, analytical texture determinations were performed. The ripeness point of each avocado 
variety was characterized by the following results in kilograms (mean \pm standard deviation): Wilson Popenoe, 1.32 \pm 0.29 ; Figueroa 1, 1.18 \pm 0.21 ; Waldin, 0.92 \pm 0.11 ; Puebla, 0.91 \pm 0.24 ; Schaff, 1.57 \pm 0.25 ; Celia, $1.09 \pm 0.16$; Araira FM, 0.81 \pm 0.13 ; Adolfo, 0.95 \pm 0.23 ; Esencia de la Vega, 1.23 \pm 0.11 ; Lawhon, 0.95 \pm 0.02 ; Winslowson, $1.20 \pm 0.11$; and Lujo, $0.86 \pm 0.05$.

Only data on four varieties (Waldin, Puebla, Schaff and Winslowson) were found in the literature, so this could be the first time that the other eight varieties are depicted.

Comparing data on fruit characteristics from different countries is very difficult because different factors can induce variability even in the same orchard and at different harvesting seasons (Salazar et al., 1971), but there is no other way to contrast data from different sources.

Comparing data of oil content of this work (TABLE 1) with previous reports, the oil percentage of Waldin is in agreement with a previously published data (California Avocado Society, 1946), but for Winslowson is higher (Salazar et al., 1971) and for Puebla very much lower (California Avocado Society, 1946).

Oil and moisture percentages are constant cgaracteristics very useful to know oil percentages from moisture determinations according to some reports (ElZeftawi, 1978; Brown, 1984). In this work, these values were between 87.48 (Waldin) and 93.21 (Schaff) (TABLE 1).

Fruits of the Puebla variety were the smallest (TABLE 2), and also the lightest $(p<0.05)$ (TABLE 3 ) in this category and among the 49 ones characterized from the indicated orchard. However, there have been characterized other lighter fruit varieties, like the $75 \mathrm{~g}$ weight Caliente (Vogel, 1958).

Puebla, Waldin and Winslowson were lighter than the range of weights reported by California Avocado Society (1946), and Waldin also lighter than the values reported by Fersini (1975), but Winslowson was heavier than the weight registered by Salazar et al. (1971).

According to descriptors employed by Avilán et al. (1994) Schaff, Winslowson, and Adolfo varieties were very heavy; Lujo, Araira FM, and Wilson Popenoe were heavy; Figueroa 1 and Lawhon were medium; Celia and Esencia de la Vega light; and Waldin and Puebla very light.

Wilson Popenoe was the variety with the highest pulp proportion $(p<0.05)$ in this category (TABLE 2$)$ and among the 49 varieties characterized from the indicated orchard. This maximum is lower than the values reached by varieties from other places, like Valle 5 from Colombia (88\%) (Salazar et al., 1971) and Alboyce from Texas (88\%) (Rouse \& Knight Junior, 1991). It is interesting to point out that the varieties cucumber shaped like Russell (GómezLópez, 1998) and Wilson Popenoe were two of the four varieties with highest pulp percentages among the 49 studied in this project, and Alboyce has also a cucumber shape, so it might be some relationship between this shape and a very high pulp ratio. According to descriptors employed by Avilán et al. (1994) Wilson Popenoe and
Schaff had high pulp percentage; Winslowson, Adolfo, and Lawhon medium pulp percentage; and Lujo, Araira FM, Esencia de la Vega, Figueroa 1, Waldin, Puebla, and Celia had low pulp percentage.

Seven varieties were oval, four pyriform and one cucumber shaped (TABLE 4). Schaff had an almost rhomboid shape, and Winslowson was almost round. Five had smooth peel and 7 rough peel. The rough texture is related to the development of extensive corky areas in the external fruit surface (Schroeder, 1950) rather than the irregular surface exemplified by the Hass variety. Two varieties had purple peel (positive chromaticity value $a$, TABLE 4), which might be due to anthocyanin pigments as was obtained by Prabha et al. (1980) in an unidentified

TABLE 3 - Size ${ }^{a}$ of twelve Avocado Varieties harvested in Venezuela in 1993.

\begin{tabular}{lcc}
\hline Variety & \multicolumn{1}{c}{ Length } & Width \\
\hline & $-17.82 \pm 1.75$ & $6.26 \pm 0.32$ \\
Wilson Popenoe & $12.74 \pm 0.63$ & $7.82 \pm 0.54$ \\
Figueroa 1 & $8.56 \pm 0.46$ & $6.30 \pm 0.29$ \\
Waldin & $7.90 \pm 0.10$ & $4.62 \pm 0.16$ \\
Puebla & $15.54 \pm 1.42$ & $8.80 \pm 0.80$ \\
Schaff & $9.68 \pm 0.81$ & $6.60 \pm 0.25$ \\
Celia & $12.46 \pm 0.63$ & $7.79 \pm 0.32$ \\
Araira FM & $15.92 \pm 1.53$ & $8.16 \pm 0.61$ \\
Adolfo & $11.72 \pm 0.38$ & $6.16 \pm 0.34$ \\
Esencia de la Vega & $10.42 \pm 0.45$ & $7.18 \pm 0.18$ \\
Lawhon & $11.74 \pm 0.21$ & $9.14 \pm 0.21$ \\
Winslowson & $14.94 \pm 0.76$ & $7.34 \pm 0.33$ \\
\hline Lujo &
\end{tabular}

Data are means of five avocados.

TABLE 4 - External Characteristics of 12 Avocado Varieties $^{\text {a }}$ Harvested in Venezuela in 1993.

\begin{tabular}{|c|c|c|c|c|c|}
\hline Variety & Shape & Peel texture & $\mathrm{L}^{\mathrm{b}}$ & $a^{c}$ & $b^{d}$ \\
\hline $\begin{array}{l}\text { Wilson } \\
\text { Popenoe }\end{array}$ & Cucumber & Smooth & 41 & -7 & 52 \\
\hline Figueroa 1 & Ovate & Smooth & 42 & -10 & 48 \\
\hline Waldin & Ovate & Smooth & 37 & -6 & 48 \\
\hline Puebla & Ovate & Rough & 23 & 3 & 11 \\
\hline Schaff & Ovate & Smooth & 29 & -10 & 43 \\
\hline Celia & Ovate & Rough & 12 & 7 & 1 \\
\hline Araira FM & Pyriform & Rough & 26 & -5 & 23 \\
\hline Adolfo & Pyriform & Rough & 27 & -2 & 21 \\
\hline $\begin{array}{l}\text { Esencia de } \\
\text { la Vega }\end{array}$ & Pyriform & Rough & 56 & -6 & 46 \\
\hline Lawhon & Ovate & Rough & 21 & -1 & 18 \\
\hline Winslowson & Ovate & Rough & 29 & -8 & 34 \\
\hline Lujo & Pyriform & Smooth & 37 & -8 & 36 \\
\hline
\end{tabular}

${ }^{a}$ Color data are means of five readings taken at the equator of five avocados. bLightness. 'Red/green chromaticity. ${ }^{\mathrm{d} Y e l l o w} / \mathrm{blue}$ chromaticity. 
variety; the other varieties were green-peeled (negative chromaticity value a).

The varieties used in this work were easy to hand peel, excluding Adolfo, Araira FM, and Lawhon; the first one had a very adherent peel, and the others a very adherent and easy to broke peel.

Peak ripeness time, the after harvest time when the highest amount of samples of each variety ripen, was 3 days for Adolfo; 4 days for Esencia de la Vega; 6 days for Figueroa 1, Waldin and Winslowson; 7 days for Araira FM, Lawhon and Wilson Popenoe; 10 days for Celia; and 12 days for Schaff. This information might be useful to select varieties because the later the peak ripening, the longer the storage life.

The estimated average potential yields were for Waldin: $11276 \mathrm{~kg}$ of fruit ha- $; 7217 \mathrm{~kg}^{-1}$ of pulp ha- ${ }^{-1}$ and 631 $\mathrm{kg}$ of oil ha-1; and for Schaff: $49273 \mathrm{~kg}^{-1}$ fruit ha' ${ }^{-1} ; 37447$ $\mathrm{kg}$ of pulp ha-1 and $3352 \mathrm{~kg}$ of oil ha- ${ }^{-1}$. Data for the other varieties were not available. Only Schaff has a potential yield higher than the one considered suitable for this crop, 16-20 ton ha' (Avilán et al., 1994), although both have a potential yield higher than the average Venezuelan yield, 3.9-4.5 ton ha-1 (MAC, 1992).

\section{ACKNOWLEDGMENT}

The author thanks Luís Avilán of the CENIAP, Venezuela, for providing all the plant materials, and for several advices.

\section{REFERENCES}

AVILÁN, L.; CIURANA, J. El aguacate (Persea americana Mill) en Venezuela. Situación actual y perspectivas. Fruits, v.38, p.183-188, 1983.

AVILÁN, L.; RODRÍGUEZ, M. El aguacatero. Carta AgrícolaFonaiap, v.14, p.1-4, 1992.

AVILÁN, L.; RODRÍGUEZ, M. Epoca de floración y cosecha del aguacate en la región norte de Venezuela. Agronomía Tropical, v.45, p.35-50, 1995.

AVILÁN, L.; RODRÍGUEZ, M.; CARREÑO, R.; DORANTES, I. Selección de variedades de aguacate. Agronomía Tropical, v.44, p.593-618, 1994.

BERGH, B. Nutritious value of avocado. California Avocado Society Yearbook, v.76, p.123-135, 1992.

BROWN, B.I. Market maturity indices and sensory properties of avocados grown in Queensland. Food Technology in Australia, v.36, p.474-476, 1984.

California Avocado Society. Check list of avocado varieties. California Avocado Society Yearbook, v.30, p.29-53, 1946.

EL-ZEFTAWI, B.M. Physical and chemical changes in fruit of seven avocado cultivars at Mildura. Australian Journal of Agricultural Research, v.29, p.81-88, 1978.
FERSINI, A. El Cultivo del Aguacate. Mexico City: Diana, 1975.

FIGUEROA, M. Cultive aguacates. Fonaiap Divulga, v.1, p.21-24, 1982.

FRANCIS, F.J.; CLYDESDALE, F.M. Food colorimetry: theory and applications. Westport: Avi Publishing, 1975. 477p.

GÓMEZ-LÓPEZ, V.M. Characterization of avocado (Persea americana Mill.) varieties of very low oil content. Journal of Agricultural and Food Chemistry, v.46, p.3643-3647, 1998.

GÓMEZ-LÓPEZ, V.M. Characterization of avocado (Persea americana Mill.) varieties of low oil content. Journal of Agricultural and Food Chemistry, v.47, p.2707-2710, 1999.

LEWIS, C.E. The maturity of avocados-a general review. Journal of the Science of Food and Agriculture, v.29, p.857-866, 1978.

LEWIS, C.E.; DETTMAN, E.; BATTYE, W. The use of test panels in evaluating the maturity of NSW avocados. Food Technology in Australia, v.31, p.394-396, 1979.

LIZANA, L.A.; LUZA, J.G. Caracterización de la fruta de paltos (PERSEA AMERICANA MILL) de la raza mexicana cultivados en Chile. Proceedings of the American Society for Horticultural Science Tropical Region, v.23, p.113-118, 1979.

MAC. Anuario Estadístico. Caracas: Ministerio de Agricultura y Cría. 1992.

OLAETA, J.A.; GARDIZABAL, F.; MARTINEZ, O. Variación estacional en el contenido de aceite y su relación con la palatabilidad en frutos de palto (Persea americana Mill.). Agricultura Técnica (Chile), v.46, p.365-367, 1986.

PEARSON, D. Seasonal English market variations in the composition of South African and Israeli avocados. Journal of the Science of Food and Agriculture, v.26, p.207-213, 1975.

PRABHA, T.N.; RAVINDRANATH, B.; PATWARDHAN, M.V. Anthocyanins of avocado (Persea americana Mill.) peel. Journal of Food Technology, v.17, p.241-242, 1980.

ROUSE, R.E.; KNIGHT JUNIOR, R.J. Evaluation and observations of avocado cultivars for subtropical climates. Proceedings of the Florida State Horticultural Society, v.104, p.24-27, 1991.

SALAZAR, R.; RÍOS, D.; TORRES, R. Selección de variedades de aguacate (Persea americana Mill.) en Colombia. Revista del Instituto Colombiano Agropecuario, v.6, p.357-377, 1971.

SCHROEDER, C.A. The structure of the skin or rind of the avocado. California Avocado Society Yearbook, v.34, p.169- 176, 1950.

STOREY, W.B.; BERGH, B.O.; WHITSELL, R.H. Factors affecting the marketability of avocado fruit. California Avocado Society Yearbook, v.57, p.33-39, 1973/74.

SWISHER, H.E. Avocado oil from food use to skin care. Journal of the American Oil Chemical Society, v.65, p.1704-1706, 1988.

VOGEL, R. Caractéristiques de quelques variétés d'avocatiers cultivés au Maroc. Fruits, v.13, p.507-509, 1958.

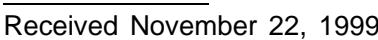

